\title{
Structural and thermal properties of tetrahedrites prepared by FAST method
}

\author{
Strukturalne i cieplne właściwości tetraedrytów \\ otrzymywanych techniką FAST
}

RAJU CHETTY
KRZYSZTOF WOJCIECHOWSKI *

DOI: 10.17814/mechanik.2016.5-6.61

Międzynarod owa Konferencja IMT 2016
In this investigation, a parent compound $\mathrm{Cu}_{12} \mathrm{Sb}_{4} \mathrm{~S}_{13}$ and doped compound $\mathrm{Cu}_{11} \mathrm{ZnSb}_{4} \mathrm{~S}_{13}$ is prepared by solid state synthesis followed by the Field Assisted Sintering Technique. XRD reveals tetrahedrite as a main phase and trace amount of impurity phases. Effect of doping on thermal conductivity of tetrahedrite is discussed.

KEYWORDS: tetrahedrite, Field Assisted Sintering Technique, thermal conductivity

Przeprowadzono badania czystego tetraedrytu o składzie $\mathrm{Cu}_{12} \mathrm{Sb}_{4} \mathrm{~S}_{13}$ oraz domieszkowanego $\mathrm{Cu}_{11} \mathrm{ZnSb}_{4} \mathrm{~S}_{13}$ otrzymanego na drodze syntezy w stanie stałym, a następnie prasowanego techniką FAST. Badania XRD potwierdziły obecność głównej fazy o strukturze tetraedrytu oraz śladową ilość zanieczyszczeń. Omówiono wpływ domieszkowania na przewodność cieplną tetraedrytu. SŁOWA KLUCZOWE: tetraedryt, spiekanie wspomagane prądem FAST, przewodność cieplna

Since few decades, there is a large focus on research of finding new thermoelectric materials which convert thermal energy into electrical energy for the waste heat recovery. A good thermoelectric materials should possesses large Seebeck coefficient $(\alpha)$ and electrical conductivity $(\sigma)$ whereas low thermal conductivity $(\kappa)$ and related by thermoelectric figure of merit $(z T=\alpha 2 \sigma T / \kappa)$. Recently, tetrahedrites are becoming promising materials for thermoelectric applications because of their complex crystal structure possesses 58 number of atoms per unit cell and shows a low thermal conductivity [1]. An improvement in thermoelectric figure of merit for these can be achieved by doping and studied by several researchers $[2 \div 6]$. In the present investigation, effect of doping on thermal conductivity of FAST samples followed by XRD and SEM is studied.

\section{Experimental details}

$\mathrm{Cu}_{12} \mathrm{Sb}_{4} \mathrm{~S}_{13}$ and $\mathrm{Cu}_{11} \mathrm{ZnSb}_{4} \mathrm{~S}_{13}$ compounds were prepared by solid state synthesis method [3]. High purity elements were weighed in stoichiometric ratio into a quartz ampoule and sealed under vacuum. Then the quartz ampoules were slowly heated to $973 \mathrm{~K}$, held at that temperature for 3 hours and then cooled to $823 \mathrm{~K}$ for 30 hours. Then the furnace was switched off to cool down to room temperature. The resulting ingots were ground into fine powder by ball milling and shaped into pellets by cold pressing. These cold pressed pellets were annealed at $773 \mathrm{~K}$ for 30 hours in evacuated quartz tubes. The annealed samples were re-

*Dr Raju Chetty (chettyraj@gmail.com), prof. Krzysztof Wojciechowski (wojciech@agh.edu.pl) - Wydział Inżynierii Materiałowej i Ceramiki, Akademia Górniczo-Hutnicza ground, loaded into graphite dies with a diameter of $10 \mathrm{~mm}$, and then compacted by using the Field Assisted Sintering Technique (FAST) at a pressure of $\sim 56 \mathrm{MPa}$ under Ar atmosphere at $723 \mathrm{~K}$ for 15 minutes.

Powder X-ray diffraction (XRD) patterns of both FAST samples were collected on a PANanalytical Empyrean instrument using $\mathrm{Cu} \mathrm{K}_{\alpha}$ radiation. Rietveld refinement was carried out for the crystallographic phase identification using the Fullprof software [7]. Cylindrical samples were cut into discs with $10.0 \mathrm{~mm}$ diameter and a thickness of $2.0 \mathrm{~mm}$ for thermal conductivity measurements using the NETZSCH LFA 457 apparatus.

\section{Results and Discussion}

- XRD (X-Ray Diffraction) Powder XRD patterns of both samples are shown in Fig. 1 and peaks are indexed to the cubic tetrahedrite as main phase $\mathrm{Cu}_{12} \mathrm{Sb}_{4} \mathrm{~S}_{13}$ (ICSD\#25707) which belongs to space group $\sqrt{4} 3 \mathrm{~m}$.

Undoped sample showed a minor impurity phases of $\mathrm{Cu}_{3} \mathrm{SbS}_{4}$ and $\mathrm{CuSbS}_{2}$ whereas doped sample showed $\mathrm{CuSbS}_{2}$ and $\mathrm{Cu}_{1.8} \mathrm{~S}$ respectively. Further, powder XRD of both samples was fitted by Rietveld refinement using the Fullprof Suite.

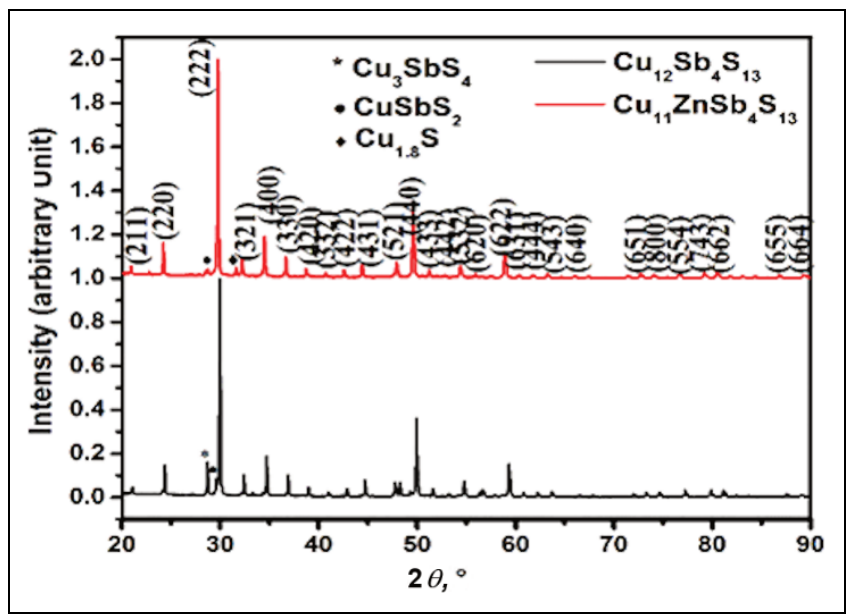

Fig. 1. Powder XRD pattern of $\mathrm{Cu}_{12} \mathrm{Sb}_{4} \mathrm{~S}_{13}$ and $\mathrm{Cu}_{11} \mathrm{ZnSb}_{4} \mathrm{~S}_{13}$

Fig. 2 shows the Rietveld refinement of undoped compound $\mathrm{Cu}_{12} \mathrm{Sb}_{4} \mathrm{~S}_{13}$. Rietveld refinement results further confirm major phase as tetrahedrite with additional impurity phases. Lattice parameters of both samples determined from the Rietveld refinement and it showed that lattice parameter a value increased with increase of doping content from value of $10.3227 \AA$ to $10.3969 \AA$, which may be due to the effect of partial substitution of $\mathrm{Zn}$ on to the Cu site. 
- SEM (Scanning Electron Microscopy). Fig. 3 shows the back scattered electron images of SEM with magnification of $500 \times$ for both samples after the Field Assisted Sintering. Micrographs of SEM clearly evidences the presence of main phase of tetrahedrite in addition with impurity phases. This results are in well agreement with the XRD results.

The presence of porosity was observed in both the cases could be the result of not sufficient temperature and/or the sintering time was applied. The presence of impurity phase might be due to the insufficient annealing temperature during the synthesis. Elemental composition was analyzed by Energy Dispersive Spectroscopy and revealed that undoped and doped samples are almost in agreement with nominal composition.

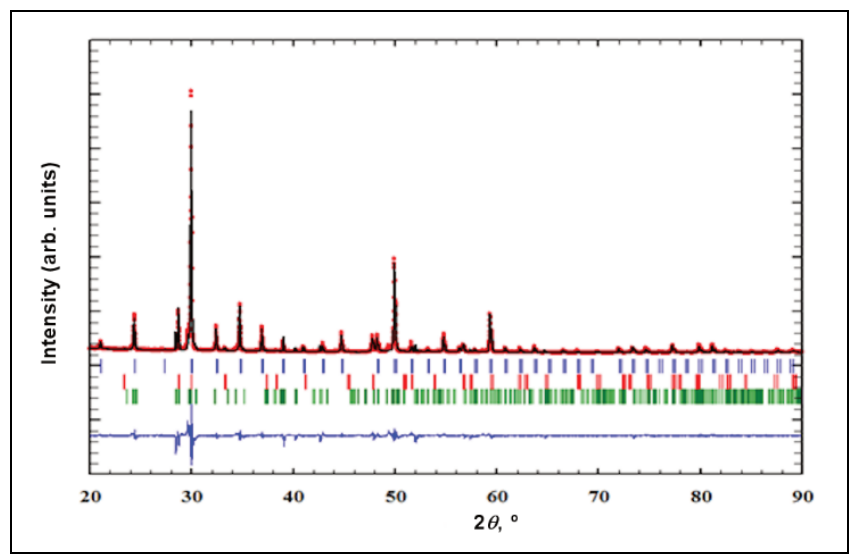

Fig. 2. Rietveld refinement of $\mathrm{Cu}_{12} \mathrm{Sb}_{4} \mathrm{~S}_{13}$
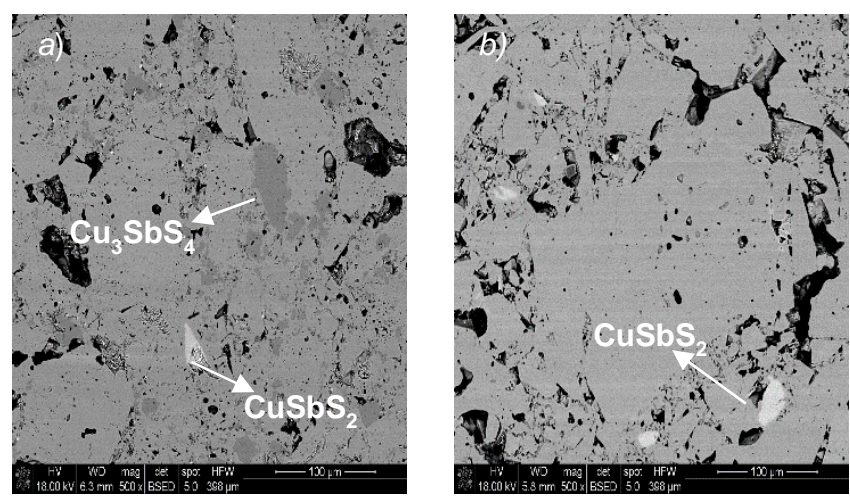

Fig. 3. Back scattered electron images of SEM for: a) $\mathrm{Cu}_{12} \mathrm{Sb}_{4} \mathrm{~S}_{13}$ b) $\mathrm{Cu}_{11} \mathrm{ZnSb}_{4} \mathrm{~S}_{13}$ samples

- Thermal conductivity. Fig. 4 shows temperature dependent thermal conductivity of $\mathrm{Cu}_{12} \mathrm{Sb}_{4} \mathrm{~S}_{13}$ and $\mathrm{Cu}_{11} \mathrm{ZnSb}_{4} \mathrm{~S}_{13}$.

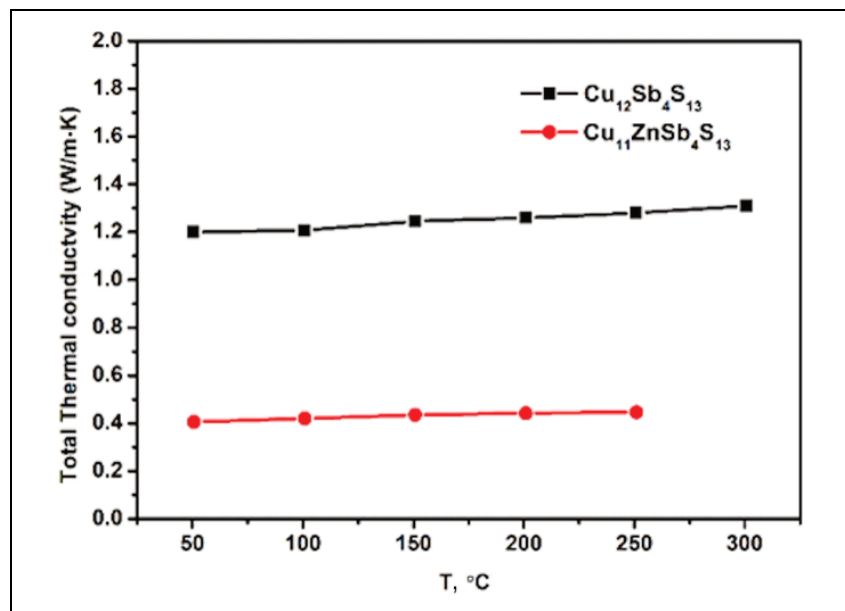

Fig. 4. Temperature dependent thermal conductivity of $\mathrm{Cu}_{12} \mathrm{Sb}_{4} \mathrm{~S}_{13}$ and $\mathrm{Cu}_{11} \mathrm{ZnSb}_{4} \mathrm{~S}_{13}$ samples
Thermal conductivity of doped sample decrease in comparison with undoped sample. This is mainly due to the two reasons, one is the decrease of carrier part of thermal conductivity and other is decrease of lattice part of thermal conductivity. The carrier part of thermal conductivity is expected to decrease because of the reduction of carrier concentration by substitution of $\mathrm{Zn}^{2+}$ on the $\mathrm{Cu}^{1+}$. Lattice part of thermal conductivity to be reduced due to the substitution ( $\mathrm{Zn}$ on the $\mathrm{Cu}$ site) effect, which leads to the scattering of heat carrying phonons by mass fluctuation. Also it is expected an effect of impurity phases may leads to the reduction of lattice thermal conductivity by scattering at phase boundaries. Thermal conductivity of both samples slightly increased with increase of temperature may be due to the dominance of carrier part of thermal conductivity which is in contrast to the traditional thermoelectric materials.

\section{Conclusion}

XRD and SEM revealed that FAST materials consists of tetrahedritre as main phase in addition to the impurity phases. Thermal conductivity of these compounds showed low values below $1 \mathrm{~W} / \mathrm{m} . \mathrm{K}$ at higher temperature. Tetrahedrites are promising thermoelectric materials due to their low thermal conductivity because of their complex crystal structure and electrical properties can be tunable by doping. The prepared compounds are composed of impurity phases and to be avoided for the better thermoelectric performance of materials.

\section{Authors would like to thank National Science Center for the support of this work by funding through project No. 2013/09/B/ST8/2043.}

\section{LITERATURE}

1. Suekuni K., Tsuruta K., Ariga T., Koyano M. „Thermoelectric Properties of Mineral Tetrahedrites $\mathrm{Cu}_{10} \mathrm{Tr}_{2} \mathrm{Sb}_{4} \mathrm{~S}_{13}$ with Low Thermal Conductivity". Appl. Phys. Express. Vol. 5, No. 5 (2012): pp. $051201 \div 3$

2. Lu X., Morelli D.T., Xia Y., Zhou F., Ozolins V., Chi H., Zhou X., Uher C. „High Performance Thermoelectricity in Earth-Abundant Compounds Based on Natural Mineral Tetrahedrites". Adv. Energy Mater. Vol. 3, No. 3 (2013): pp. 342 $\div 348$.

3. Suekuni K., Tsuruta K., Kunii M., Nishiate H., Nishibori E., Maki S., Ohta M., Yamamoto A., Koyano M. „High-performance thermoelectric mineral $\mathrm{Cu}_{12-x} \mathrm{Ni}_{x} \mathrm{Sb}_{4} \mathrm{~S}_{13}$ tetrahedrite". J. Appl. Phys.

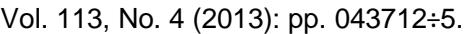

4. Chetty R., D. S P.K, Rogl G., Rogl P., Bauer E., Michor H., Suwas S., Puchegger S., Giester G., Mallik R.C, ,Thermoelectric properties of a Mn substituted synthetic tetrahedrite". Phys. Chem. Vol. 17, No. 3 (2015): pp. $1716 \div 1727$.

5. Chetty R., Bali A., Naik M.H., Rogl G., Rogl P., Jain M., Suwas S., Mallik R. C. "Thermoelectric properties of Co substituted synthetic tetrahedrite". Acta. Mater. Vol. 100 (2015): pp. $266 \div 274$.

6. Chetty R., Bali A., Mallik R.C. „Tetrahedrites as thermoelectric materials: an overview". J. Mater. Chem. C, Vol. 3, No. 48 (2015): pp. $12364 \div 12378$.

7. Roisnel T, Rodriguez-Carvajal J., „WinPLOTR: A Windows tool for powder diffraction pattern analysis”. Mat. Sci. Forum. Vol. 378-381 (2001): pp. 118-123. 